\title{
IMPLEMENTASI MESIN INFERENSI FUZZY (STUDI KASUS SISTEM PAKAR UNTUK MENDIAGNOSA PENYAKIT TANAMAN CABE MERAH)
}

\author{
Wilis Kaswidjanti \\ Jurusan Teknik Informatika UPN "Veteran" Yogyakarta \\ Jl. Babarsari 2 Tambakbayan 55281 Telp (0274) 485323 \\ e-mail : wilisk@yahoo.com
}

\begin{abstract}
Research was conducted based on the need for a tool for farmers in determining disease in red chilli plants and how to control it so as not not wrong in taking peptisida. The tool is an expert system which in addition to diagnosis, the system is expected to provide suggestions for control. Basically the software consists of two main parts, namely the input knowledge base, and the consultation. Decisions taken by using the rules. Inference method used is the fuzzy inference method with defuzzyfication using max-min method and the center average. The output of this software are the types of diseases that attack plants and its control in accordance with the advice of the devastation wrought on the red chilli plants.

Keywords : Expert System, Fuzzy Inference Machine, Red Chili, Max-Min Method

Penelitian ini dilakukan berdasarkan atas kebutuhan akan adanya alat bantu bagi petani dalam menentukan penyakit pada tanaman cabe merah serta bagaimana mengendalikannya agar tidak tidak keliru dalam memakai peptisida. Alat bantu tersebut merupakan sistem pakar yang selain untuk mendiagnosis, sistem ini diharapkan mampu memberikan saran-saran pengendalian. Pada dasarnya perangkat lunak ini terdiri atas dua bagian utama, yaitu bagian input basis pengetahuan, dan bagian konsultasi. Keputusan yang diambil dengan menggunakan metode aturan. Metode inferensi yang digunakan adalah metode inferensi fuzzy dengan defuzzifikasi menggunakan metode max-min dan center average. Keluaran dari perangkat lunak ini adalah jenis penyakit yang menyerang tanaman dan saran pengendaliannya sesuai dengan besar kerusakan yang dialami pada tanaman cabe merah.

Kata kunci : Sistem Pakar, Mesin Inferensi Fuzzy, Cabe Merah, Metode Max-Min
\end{abstract}

\section{PENDAHULUAN}

Seiring perkembangan jaman, peran komputer semakin mendominasi kehidupan manusia. Awalnya komputer hanya sebagai alat hitung saja, namun saat ini komputer sudah dapat melakukan pemrosesan data dan informasi sesuai dengan kemampuan komputer untuk menirukan kemampuan manusia yang memiliki kecerdasan. Sehingga timbul ide dari pemakai untuk memproses data (database) dengan menggunakan kecerdasan (intelligence) guna menyelesaikan suatu masalah. Salah satu bidang riset Artificial Intelligence (Al) yang cukup berkembang dewasa ini adalah sistem pakar. Saat ini sistem pakar banyak ditemui dan dibutuhkan dalam dunia kesehatan, industri maupun pendidikan, demikian juga di bidang pertanian.

Hama dan penyakit senantiasa dijumpai pada setiap tanaman tidaklah asing lagi bagi petani, tetapi masalahnya adalah apakah hama atau penyakit tersebut menimbulkan kerugian yang berarti atau tidak. Namun ini merupakan kendala yang sering dihadapi petani. Terjadinya kegagalan panen, terutama pada tanaman sayuran/palawija khususnya tanaman cabe merah dapat disebabkan bencana alam yang melanda suatu daerah tertentu dan juga terserang oleh hama dan penyakit. Sebagian besar kegagalan panen disebabkan karena tanaman diserang oleh hama dan penyakit. Kadang-kadang petani tahu kalau tanamannya diserang hama/penyakit, tetapi petani tidak tahu hama/penyakit apa yang sedang menyerang tanamannya. Penyuluh pertanian juga kesulitan untuk mengidentifikasi jenis hama dan penyakit yang menyerang tanaman, walaupun terlihat adanya perubahan tanaman. Bahkan kadangkadang penyuluh tidak tahu obat yang digunakan untuk memberantas hama dan penyakit pada tanaman. Penyuluh juga kesulitan untuk memberi penjelasan kepada petani tentang gejalagejala (tanda-tanda) suatu tanaman sedang diserang hama dan penyakit. Karena itu program 
ini akan membantu meringankan dan memudahkan para petani, penyuluh pertanian dan mahasiswa pertanian untuk mengidentifikasi hama dan penyakit yang menyerang tanaman sayuran/palawija khususnya tanaman cabe merah serta obat yang akan digunakan.

Ketika para petani, penyuluh pertanian atau mahasiswa pertanian mengidentifikasikan penyakit pada tanaman cabe merah ada ketidakpastian yang terjadi, yaitu mungkin antara satu orang dengan orang lainnya tidak sama tingkat keyakinannya apakah tanaman yang didiagnosa itu berpenyakit ringan atau malah sudah berat. Hal tersebut dapat diatasi dengan menggunakan salah satu bidang ilmu di kecerdasan buatan yaitu dengan logika fuzzy. Selama ini kebanyakan sistem pakar yang dibuat bersifat statis untuk satu jenis tanaman, maksudnya sistem pakar tersebut hanya dapat menangani satu jenis tanaman saja. Data-data yang diperlukan untuk perancangan fuzzy juga bersifat statis, maksudnya ketika ada perubahan data tidak dapat diupdate sesuai perkembangan daa yang ada pada saat sistem pakar tersebut dipakai. Hal inilah yang mendorong peneliti untuk membuat sistem pakar menggunakan mesin inferensi fuzzy ini dengan nilai-nilai batas fuzzy dapat diinput oleh pakar melalui program yang akan dibuat.

\section{METODE PENELITIAN}

Metodologi penelitian yang digunakan adalah metode pengembangan sistem pakar.

Metode ini meliputi tahap :

a. Penilaian kebutuhan

Penilaian kebutuhan merupakan langkah untuk mengidentifikasi masalah dan kebutuhan dari sistem, dengan menggunakan metode wawancara salah satunya wawancara dengan pakar di bidang pertanian.

b. Koleksi pengetahuan

Tahap ini merupakan tahap pengumpulan pengetahuan atau akuisisi pengetahuan yang dibutuhkan sistem seperti gejala-gejala tanaman berpenyakit dan penyakit-penyakit yang menyerang tanaman cabe merah.

c. Perancangan

Mendesain model yang diinginkan yaitu perancangan representasi pengetahuan, perancangan mesin inferensi menggunakan fuzzy logic, perancangan sistem, diagram aliran data, perancangan basis data dan perancangan antarmuka (interface) sistem.

d. Implementasi dan Testing

Menguji coba sistem yang telah dibuat.

\section{HASIL PENELITIAN DAN PEMBAHASAN}

\subsection{Akuisisi Pengetahuan}

Pengetahuan yang digunakan untuk membangun sistem diperoleh dari beberapa sumber pengetahuan yaitu buku, dokumen yang berisi data gejala-gejala penyakit tanaman, dan pakar dalam bidang penyakit tanaman.

Pengetahuan tersebut meliputi :

1. gejala-gejala yang menyerang tanaman dilihat dari bagian tanaman yang utama;

2. tingkat kerusakan yang timbul dari gejala-gejala yang tampak;

3. berat serangan penyakit serta pengendaliannya.

Pengetahuan ini selanjutnya diekstrak dari sumber-sumber pengetahuan untuk kemudian direpresentasikan ke dalam basis pengetahuan.

Pada penelitian ini, contoh kasus untuk menentukan penyakit diteliti pada tanaman cabe merah. Salah satu faktor yang mempengaruhi petani dalam mengambil keputusan dalam pengendalian penyakit tanaman adalah perasaan atau intuisi petani tentang besarnya kerusakan yang diakibatkan oleh serangan penyakit di lapangan. Penentuan penyakit dilakukan dengan melihat gejala-gejala yang terdapat pada tanaman. Pengamatan penyakit dapat dilakukan untuk mengetahui sejauh mana tanaman terserang oleh penyakit. Pengamatan yang dilakukan pada tanaman sampel yang tersebar dalam suatu luasan tertentu untuk memperoleh data tingkat kerusakan tanaman. Semua tanaman sampel yang terdapat pada setiap petak sampel diamati. Pengamatan dilakukan pada bagian tanaman dalam rumpun yang bersangkutan.

Berat serangan dibagi menjadi empat tingkat yakni ringan, sedang, berat dan puso (Anonim,1990). 
1. ringan, yaitu derajat serangan yang sama atau lebih besar dari batas toleransi terendah yang telah ditetapkan sampai di bawah 25.0 persen;

2. sedang, yaitu derajat serangan yang sama atau lebih besar dari 25.0 persen sampai di bawah 50.0 persen;

3. berat, yaitu derajat serangan yang sama atau lebih besar dari 50.0 persen sampai di bawah 75.0 persen;

4. puso, yaitu derajat serangan yang sama atau lebih besar dari 75.0 persen.

Pada penelitian ini, tingkat kerusakan dibuat menjadi empat tingkat, yaitu sedikit, sedang, banyak dan sangat banyak dengan range persentase $0-100 \%$. Interval tingkat kerusakan dapat dilihat pada tabel 3.1.

Tabel 3.1 Tingkat kerusakan.

\begin{tabular}{|l|l|}
\hline Tingkat kerusakan & Interval (\%) \\
\hline Sedikit & 0-di bawah 25 \\
\hline Sedang & 25-di bawah 50 \\
\hline Banyak & 50-di bawah 75 \\
\hline sangat banyak & 75-100 \\
\hline
\end{tabular}

Dari data tingkat kerusakan dan berat serangan di atas dapat dilihat bahwa interval data tidak menunjukkan perbedaan gradasi yang cukup baik. Sebagai contoh, derajat serangan $25 \%$ termasuk dalam berat serangan sedang, sedangkan $24.9 \%$ tidak termasuk berat serangan sedang tetapi berat serangan ringan. Dengan demikian, nilai derajat serangan yang hampir sama mempunyai berat serangan yang berbeda. Pendekatan logika fuzzy digunakan untuk membuat perbedaan gradasi nilai dalam setiap interval data menjadi lebih baik.

Logika fuzzy dapat digunakan untuk mentransformasi interval data ke dalam suatu nilai dari 0 sampai dengan 1 dimana 1 berarti benar secara absolut dan 0 berarti tidak benar secara absolut. Nilai kebenaran tersebut menyatakan derajat keanggotaan data dalam suatu interval data tertentu. Untuk memperoleh transformasi demikian, interval data tingkat kerusakan dan berat serangan dinyatakan dalam interval yang overlap. Interval overlap diperoleh dengan cara memperlebar kisaran (range) dari interval. Perubahan interval data tersebut didapat melalui wawancara dengan pakar.

Tabel 3.2 Tingkat kerusakan menggunakan interval overlap

\begin{tabular}{|l|l|}
\hline Tingkat Kerusakan & Interval (\%) \\
\hline Sedikit & $0-30$ \\
\hline Sedang & $20-55$ \\
\hline Banyak & $45-80$ \\
\hline Sangat banyak & $70-100$ \\
\hline
\end{tabular}

Tabel 3.3 Berat serangan menggunakan interval overlap

\begin{tabular}{|l|l|}
\hline Berat Serangan & Interval (\%) \\
\hline Ringan & $0-30$ \\
\hline Sedang & $20-55$ \\
\hline Berat & $45-80$ \\
\hline Puso & $70-100$ \\
\hline
\end{tabular}

Interval berat serangan dibagi seperti interval tingkat kerusakan, karena memperhatikan bahwa berat serangan penyakit yang menyerang tanaman sebanding dengan nilai kerusakan tanaman.

\subsection{Representasi Pengetahuan}

Setelah akuisisi pengetahuan berikutnya yang dilakukan adalah merepresentasikan pengetahuan yang dikumpulkan. Pengetahuan yang diperoleh dari tahap akuisisi direpresentasikan sehingga inferensi dapat dilakukan. Teknik representasi pengetahuan yang digunakan adalah kaidah produksi. Dalam kaidah produksi, pengetahuan dinyatakan dalam bentuk aturan IF-THEN. Bagian premis dari aturan yang digunakan untuk penentuan penyakit tanaman merupakan proposisi fuzzy yang berkaitan dengan tingkat kerusakan, sedangkan 
bagian kesimpulan berkaitan dengan berat serangan. Untuk gejala tanaman terserang penyakit, tingkat kerusakannya dinyatakan sebagai variabel linguistik dengan nilai-nilai linguistiknya adalah sedikit, sedang, banyak, dan sangat banyak. Dan untuk berat serangan penyakit dengan nilai-nilai linguistiknya adalah ringan, sedang, berat, dan puso.

\subsection{Representasi Aturan Fuzzy (Fuzzy Rule Representation)}

Berikut salah satu aturan fuzzy. Aturan ini untuk penyakit Layu Bakteri :

R1 : If layunya beberapa daun muda is sedikit and menguningnya daun tua sebelah bawah is sedikit then penyakit Layu Bakteri is ringan

$\mathrm{R} 2$ : If layunya beberapa daun muda is sedikit and menguningnya daun tua sebelah bawah is sedang then penyakit Layu Bakteri is sedang

R3 : If layunya beberapa daun muda is sedikit and menguningnya daun tua sebelah bawah is banyak then penyakit Layu Bakteri is berat

R4 : If layunya beberapa daun muda is sedikit and menguningnya daun tua sebelah bawah is sangat banyak then penyakit Layu Bakteri is puso

R5 : If layunya beberapa daun muda is sedang and menguningnya daun tua sebelah bawah is sedikit then penyakit Layu Bakteri is ringan

R6 : If layunya beberapa daun muda is sedang and menguningnya daun tua sebelah bawah is sedang then penyakit Layu Bakteri is sedang

R7 : If layunya beberapa daun muda is sedang and menguningnya daun tua sebelah bawah is banyak then penyakit Layu Bakteri is berat

R8 : If layunya beberapa daun muda is sedang and menguningnya daun tua sebelah bawah is sangat banyak then penyakit Layu Bakteri is puso

R9 : If layunya beberapa daun muda is banyak and menguningnya daun tua sebelah bawah is sedikit then penyakit Layu Bakteri is sedang

R10 : If layunya beberapa daun muda is banyak and menguningnya daun tua sebelah bawah is sedang then penyakit Layu Bakteri is berat

R11 : If layunya beberapa daun muda is banyak and menguningnya daun tua sebelah bawah is banyak then penyakit Layu Bakteri is berat

R12 : If layunya beberapa daun muda is banyak and menguningnya daun tua sebelah bawah is sangat banyak then penyakit Layu Bakteri is puso

R13 : If layunya beberapa daun muda is sangat banyak and menguningnya daun tua sebelah bawah is sedikit then penyakit Layu Bakteri is berat

R14 : If layunya beberapa daun muda is sangat banyak and menguningnya daun tua sebelah bawah is sedang then penyakit Layu Bakteri is berat

R15 : If layunya beberapa daun muda is sangat banyak and menguningnya daun tua sebelah bawah is banyak then penyakit Layu Bakteri is puso

R16 : If layunya beberapa daun muda is sangat banyak and menguningnya daun tua sebelah bawah is sangat banyak then penyakit Layu Bakteri is puso

\subsection{Proses Inferensi (Inference Engine)}

Secara garis besar, diagnosa penyakit tanaman dengan berat serangannya ditentukan melalui tahap inferensi berdasarkan data input yang dinyatakan sebagai nilai crisp. Proses inferensi dilakukan dengan menggunakan metode pelacakan ke belakang (backward chaining). Dalam proses inferensi, tanaman yang dimaksud diasumsikan menderita penyakit tertentu, dan dengan mencocokkan gejala-gejala yang terdapat pada tanaman yang dimasukkan untuk mendapatkan kesimpulan bahwa asumsi tersebut benar atau salah. Untuk berat serangan penyakit diperoleh berdasarkan inferensi fuzzy. Proses inferensi untuk menentukan berat serangan tersebut berdasarkan data input crisp diberikan dalam gambar 3.1.

Terdapat empat tahap dalam penentuan penyakit dari input nilai crisp berdasarkan inferensi fuzzy, yaitu fuzzifikasi, inferensi, komposisi dan defuzzifikasi. Metode inferensi yang digunakan dalam penelitian ini adalah min, sedangkan metode komposisi yang digunakan adalah max. Kombinasi kedua tersebut sering dikenal sebagai inferensi max-min. Inferensi max-min adalah metode yang paling banyak digunakan dalam mesin inferensi dalam sistem fuzzy karena memberi kemudahan dalam komputasi (Wang, 1997). Metode defuzzifikasi yang digunakan adalah center average defuzzifier. 


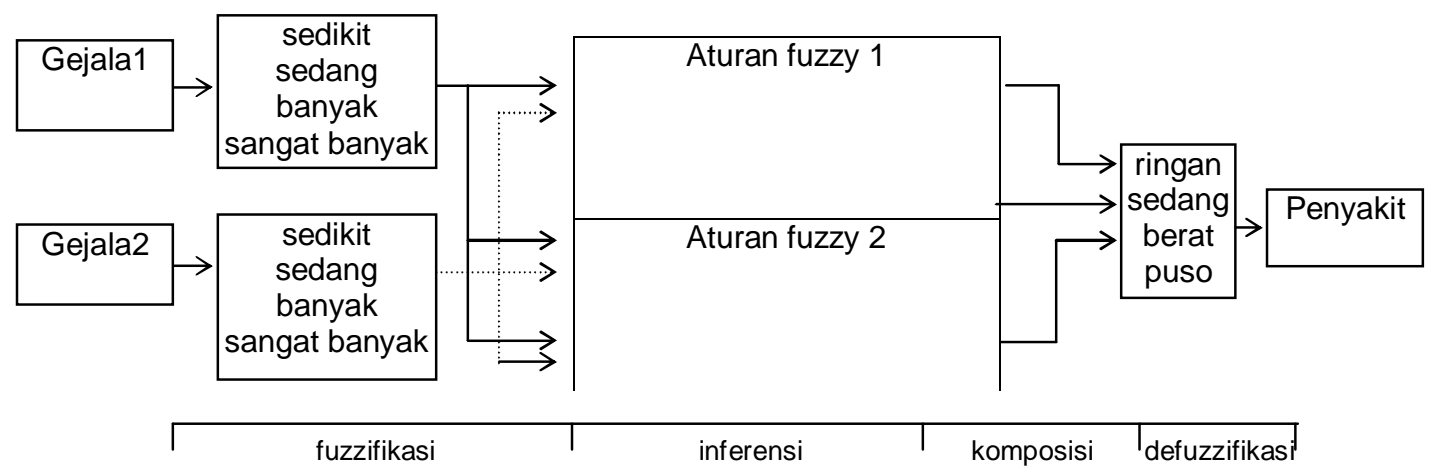

Gambar 3.1 Proses Inferensi untuk menentukan berat serangan

\subsection{Fuzzifikasi (Fuzzification)}

Fungsi keanggotaan untuk setiap tingkat kerusakan dan berat serangan adalah berbentuk trapesium dengan domain yang sama yaitu range antara 0 sampai $100 \%$. Gambar 3.2 memperlihatkan representasi himpunan fuzzy menggunakan fungsi matematika untuk fuzzifikasi.
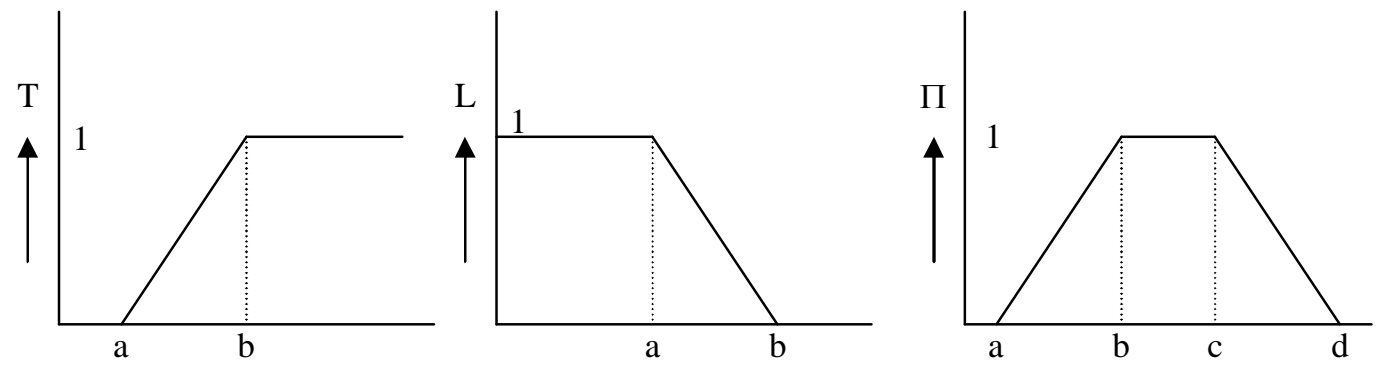

$$
T(x ; a, b)=\left\{\begin{array}{ll}
0, & x<a \\
(x-a) /(b-a), & a \leq x \leq b \\
1, & x>b
\end{array} \quad L(x ; a, b)=\left\{\begin{array}{cl}
0, & x>b \\
(b-x) /(b-a), & a \leq x \leq b \\
1, & x<a
\end{array} \quad \Pi(x ; a, b, c, d)= \begin{cases}0, & x<a \\
(x-a) /(b-a), & a \leq x<b \\
1, & b \leq x \leq c \\
(d-x) /(d-c), & c<x \leq d \\
0, & x>d\end{cases}\right.\right.
$$

Gambar 3.2 Fungsi Trapesium

Fungsi keanggotaan untuk gejala tanaman berkaitan dengan tingkat kerusakan ditunjukkan dalam Gambar 3.3, dan untuk penyakit berkaitan dengan berat serangan ditunjukkan dalam Gambar 3.4.

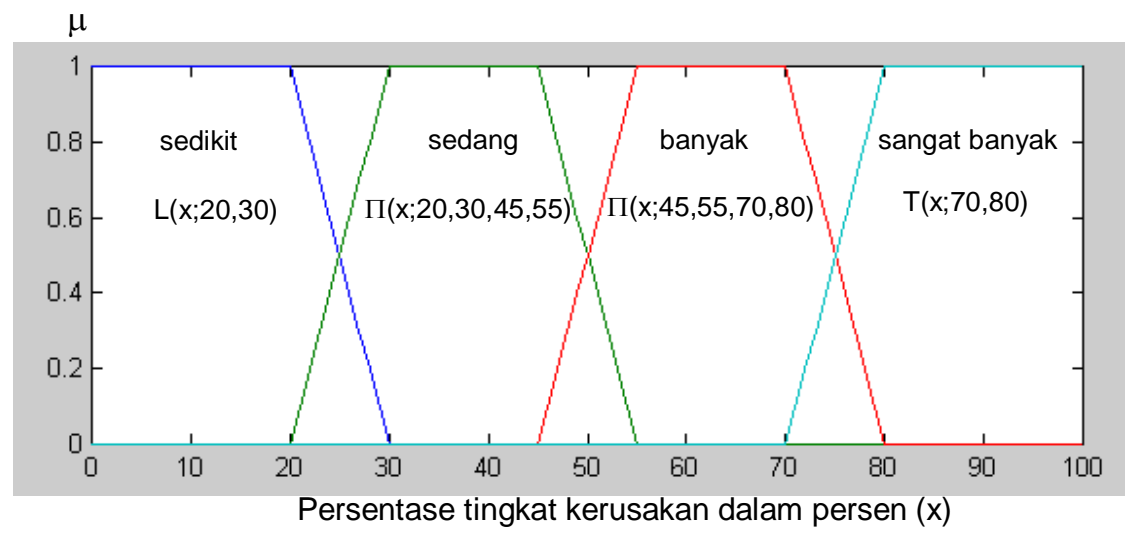

Gambar 3.3 Fungsi keanggotaan gejala tanaman berkaitan dengan tingkat kerusakan 


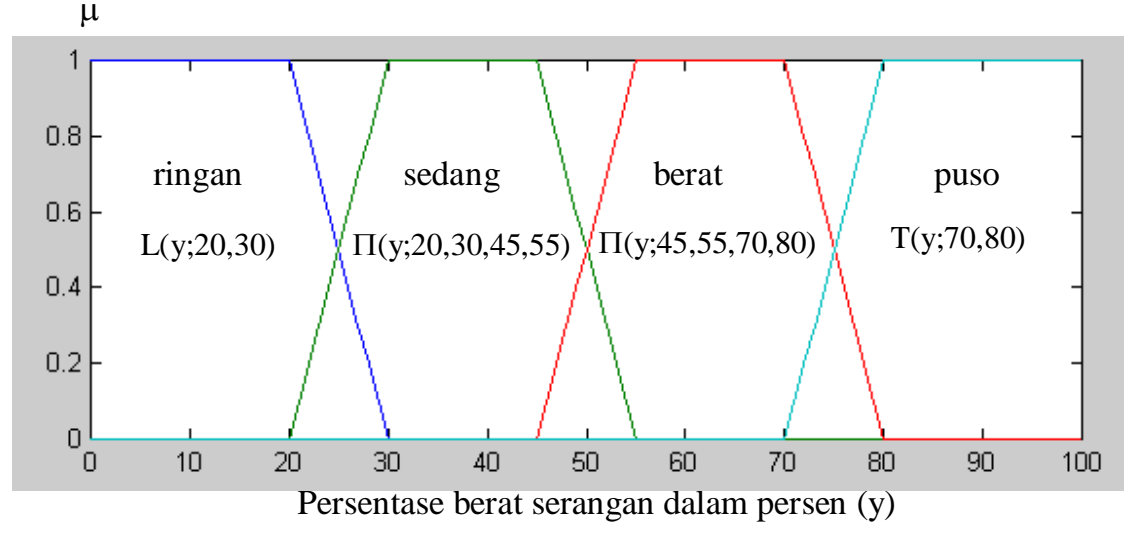

Gambar 3.4 Fungsi keanggotaan penyakit berkaitan dengan berat serangan

Nilai pusat (center) dari setiap himpunan fuzzy berat serangan diberikan dalam Tabel 3.4.

Tabel 3.4 Nilai pusat dari berat serangan.

\begin{tabular}{|c|c|}
\hline Berat Serangan & Nilai pusat \\
\hline Ringan & 12.5 \\
\hline Sedang & 37.5 \\
\hline Berat & 62.5 \\
\hline Puso & 87.5 \\
\hline
\end{tabular}

Untuk menggambarkan proses fuzzifikasi, diberikan contoh data input gejala-gejala penyakit tanaman cabe merah :

a. layunya beberapa daun muda $=y a$, dengan tingkat kerusakan $=23 \%$

b. menguningnya daun tua sebelah bawah = ya, dengan tingkat kerusakan $=25 \%$ Dari fungsi keanggotaan "layunya beberapa daun muda" dan "menguningnya daun tua sebelah bawah" dapat diperoleh nilai keanggotaan untuk data input tersebut. Nilai keanggotaan untuk data input "layunya beberapa daun muda" tidak sama dengan 0 pada kelompok sedikit dan sedang. Sedangkan nilai keanggotaan untuk data input "menguningnya daun tua sebelah bawah" tidak sama dengan 0 pada kelompok sedikit dan sedang. Nilai-nilai keanggotaan tersebut adalah :

a. layunya beberapa daun muda (uk)

$$
\begin{aligned}
& \mu_{\mathrm{uk} S E D I K I T}(23)=(30-23) /(30-20)=0.7 \\
& \mu_{\mathrm{ukSEDANG}}(23)=(23-20) /(30-20)=0.3
\end{aligned}
$$

b. menguningnya daun tua sebelah bawah (bc)

$$
\begin{aligned}
& \mu_{\mathrm{bcSEDIKIT}}(25)=(30-25) /(30-20)=0.5 \\
& \mu_{\mathrm{bcSEDANG}}(25)=(25-20) /(30-20)=0.5
\end{aligned}
$$

Dengan demikian terdapat empat aturan yang terpicu dengan premis-premisnya adalah

Premis aturan 1 (R1) : layunya beberapa daun muda is sedikit and menguningnya daun tua sebelah bawah is sedikit

Premis aturan 2 (R2) : layunya beberapa daun muda is sedikit and menguningnya daun tua sebelah bawah is sedang

Premis aturan 3 (R3) : layunya beberapa daun muda is sedang and menguningnya daun tua sebelah bawah is sedikit

Premis aturan 4 (R4) : layunya beberapa daun muda is sedang and menguningnya daun tua sebelah bawah is sedang

Dengan mengaplikasikan operator min diperoleh nilai kebenaran premis sebagai berikut :

Premis R1 $: \min \left(\mu_{\mathrm{ukSEDIKIT}}(25), \mu_{\mathrm{bC} S E D I K I T}(25)\right)=\min (0.7,0.5)=0.5$

Premis R2 $: \min \left(\mu_{\mathrm{ukSEDIKIT}}(25), \mu_{\mathrm{bcSEDANG}}(25)\right)=\min (0.7,0.5)=0.5$

Premis R3 $: \min \left(\mu_{\mathrm{ukSEDANG}}(25), \mu_{\mathrm{bcSEDIKIT}}(25)\right)=\min (0.3,0.5)=0.3$

Premis R4 $: \min \left(\mu_{\mathrm{ukSEDANG}}(25), \mu_{\mathrm{bcSEDANG}}(25)\right)=\min (0.3,0.5)=0.3$ 
Dengan menggunakan aturan untuk menentukan tingkat kerusakan penyakit yang terdiagnosa diperoleh aturan-aturan sebagai berikut :

R1 : if layunya beberapa daun muda is sedikit and menguningnya daun tua sebelah bawah is sedikit then penyakit Layu Bakteri is ringan

$\mathrm{R} 2$ : if layunya beberapa daun muda is sedikit and menguningnya daun tua sebelah bawah is sedang then penyakit Layu Bakteri is sedang

R3 : if layunya beberapa daun muda is sedang and menguningnya daun tua sebelah bawah is sedang is sedikit then penyakit Layu Bakteri is ringan

R4 : if layunya beberapa daun muda is sedang and menguningnya daun tua sebelah bawah is sedang then penyakit Layu Bakteri is sedang

\section{Inferensi $\min$}

Dalam inferensi min, fungsi keanggotaan output untuk setiap aturan diperoleh dari fungsi keanggotaan penyakit dari aturan-aturan yang terpicu yang dipotong pada ketinggian yang disesuaikan dengan nilai kebenaran premis dari aturan-aturan tersebut. Fungsi keanggotaan yang dihasilkan dari proses inferensi adalah sebagai berikut :

$$
\begin{aligned}
& \mu_{\text {Output_R1 }}(y)= \begin{cases}0.5, & 0<y<25 \\
\frac{30-y}{10}, & 25 \leq y \leq 30 \\
0, & \text { selainnya }\end{cases} \\
& \mu_{\text {Output_R3 }}(y)=\left\{\begin{array}{ll}
0.3, & 0<y<23 \\
\frac{30-y}{10}, & 23 \leq y \leq 30 \\
0, & \text { selainnya }
\end{array} \quad \text { Output_R2 }^{0}(y)= \begin{cases}\frac{0.5,}{y-20} & 25 \leq y \leq 50 \\
\frac{55-y}{10}, & 20 \leq y<25 \\
0, & 50<y \leq 55\end{cases} \right. \\
& \text { selainnya }
\end{aligned}
$$

\section{Komposisi max}

Output dari proses komposisi max adalah himpunan fuzzy yang dibentuk dari titik-titik maksimum dari semua himpunan fuzzy untuk setiap aturan yang dihasilkan dalam proses inferensi. Fungsi keanggotaan dari output yang dihasilkan dari proses komposisi adalah

$$
\mu_{\text {Output }}(y)=\left\{\begin{array}{lc}
0.5, & 0<r \leq 50 \\
\frac{55-r}{10}, & 50<r \leq 55 \\
0, & \text { selainnya }
\end{array}\right.
$$

\section{Deffuzzifikasi (Defuzzification)}

Himpunan fuzzy yang dihasilkan dari proses komposisi dikonversi ke dalam bentuk crisp dengan menggunakan metode center average defuzzifier. Misal pusat dari himpunan fuzzy output R1, R2, R3 dan R4 berturut-turut adalah $\bar{y}^{-1}=12.5, \bar{y}^{2}=37.5, \bar{y}^{3}=12.5, \bar{y}^{4}=37.5$ dan tingginya berturut-turut adalah $\mathrm{w}_{1}=0.5, \mathrm{w}_{2}=0.5, \mathrm{w}_{3}=0.3, \mathrm{w}_{4}=0.3$. Metode center average defuzzifier menentukan besar serangan penyakit $(y)$ sebagai berikut :

$$
y^{*}=\frac{12.5 \times 0.5+37.5 \times 0.5+12.5 \times 0.3+37.5 \times 0.3}{0.5+0.5+0.3+0.3}=25
$$

Dari fungsi keanggotaan berat serangan diperoleh bahwa $y^{*}=25$ termasuk ke dalam kelompok ringan dan sedang. 


\section{Implementasi sistem}

1. Menu Aturan

Menu Aturan digunakan untuk memasukkan dan menampilkan aturan-aturan fuzzy dengan data-data nama penyakit dan gejala diambil dari tabel-tabel yang disimpan dalam file basis data.

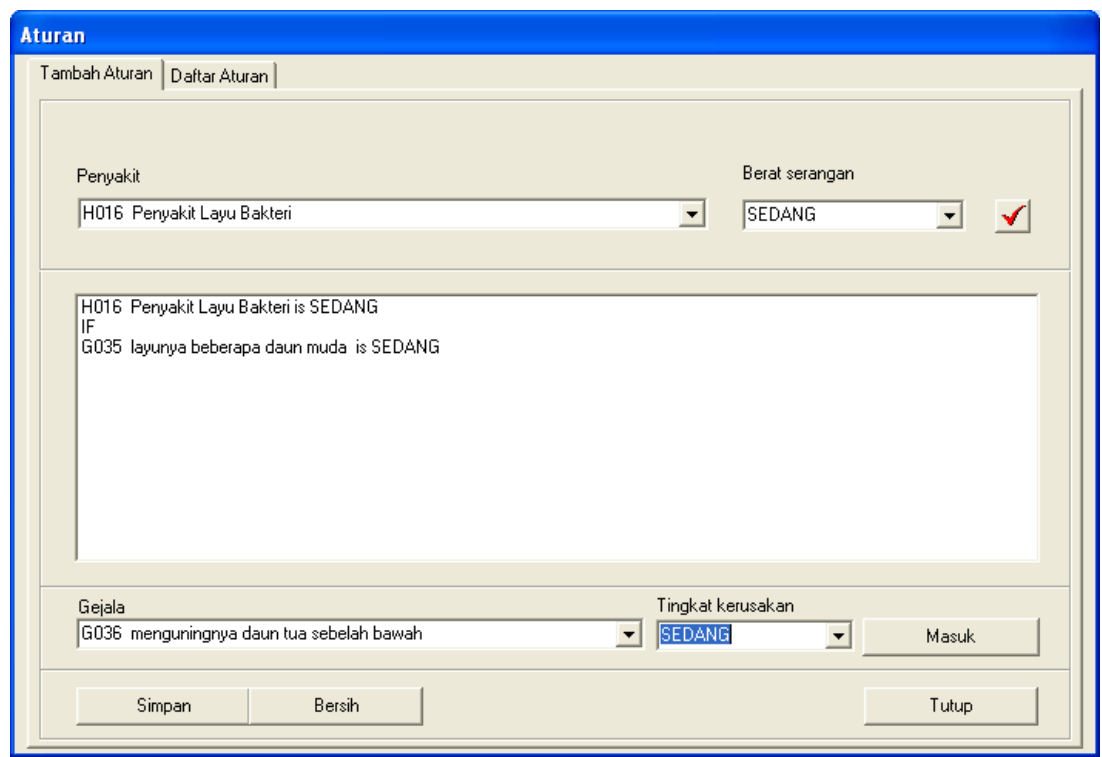

Gambar 3.5 Form input aturan fuzzy

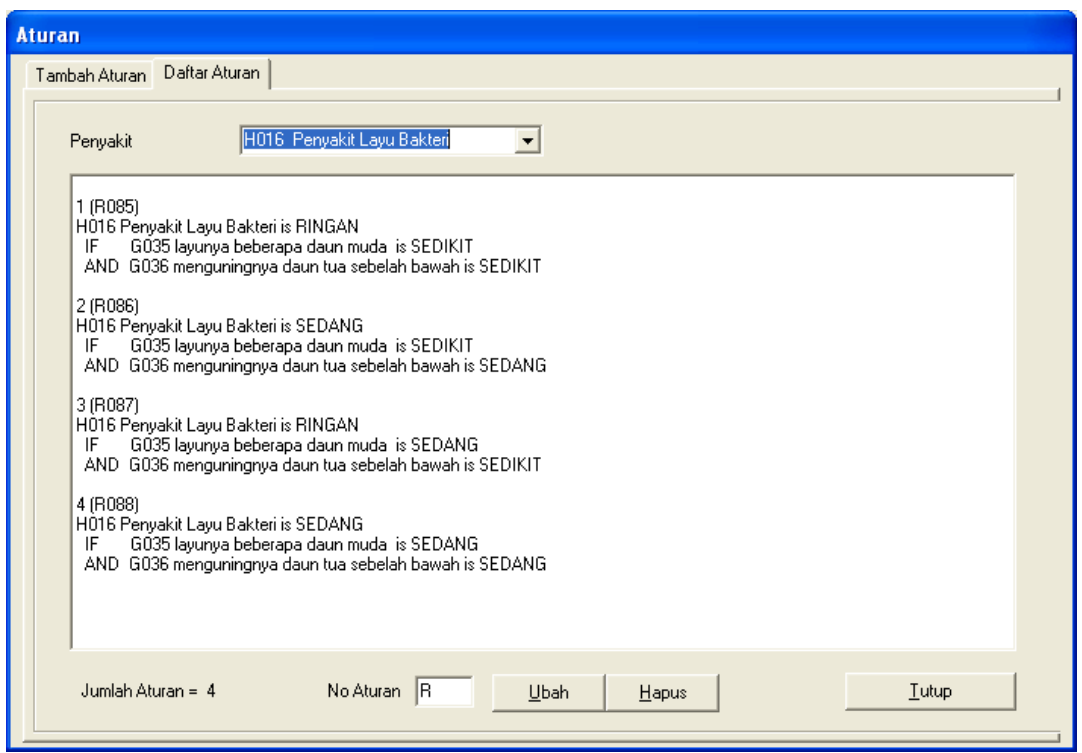

Gambar 3.6 Form lihat daftar aturan fuzzy

2. Menu Konsultasi

Menu ini merupakan form untuk konsultasi penyakit apa yang menyerang tanaman cabe merah dengan dihitung berapa persentase berat kerusakan yang terjadi pada tanaman tersebut. Dengan metode penelusuran backward chaining, pemakai hanya menjawab ya atau tidak untuk tiap gejala yang ditanyakan, dan jika ya, dimasukkan berapa persen kemungkinan tingkat kerusakannya. Ketika hasil konsultasi didapat, form ini juga menyediakan fasilitas untuk menampilkan pengendalian yang direkomendasikan untuk penyakit yang menyerang tanaman cabe merah. 


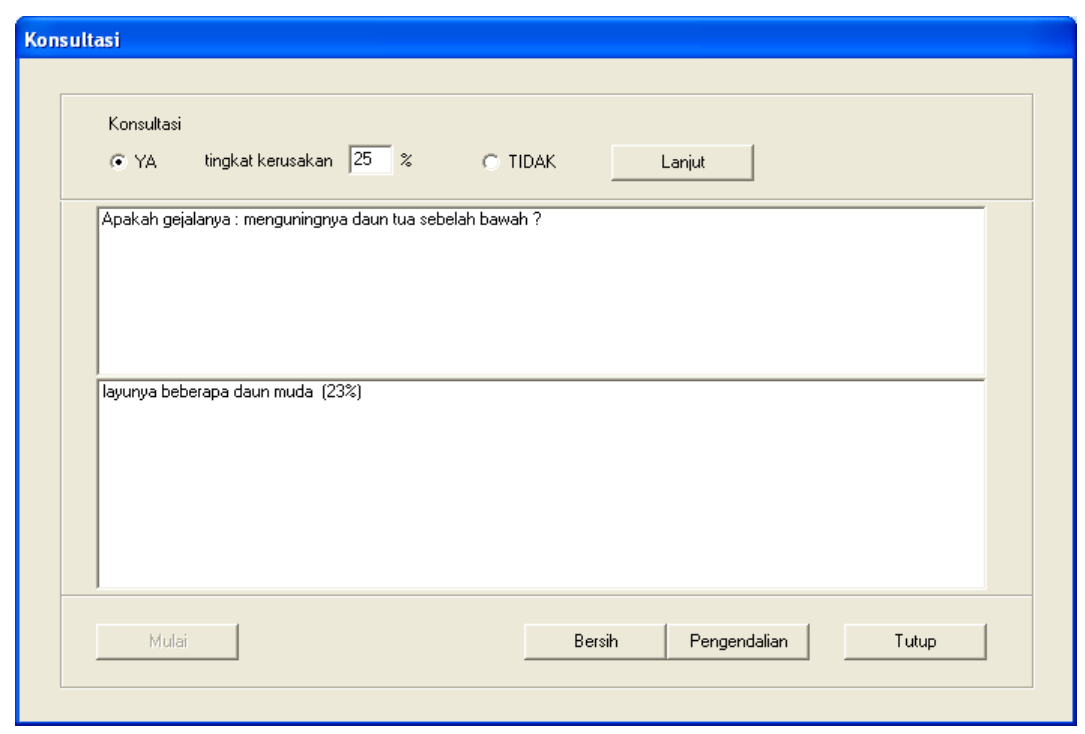

Gambar 3.7 Form konsultasi

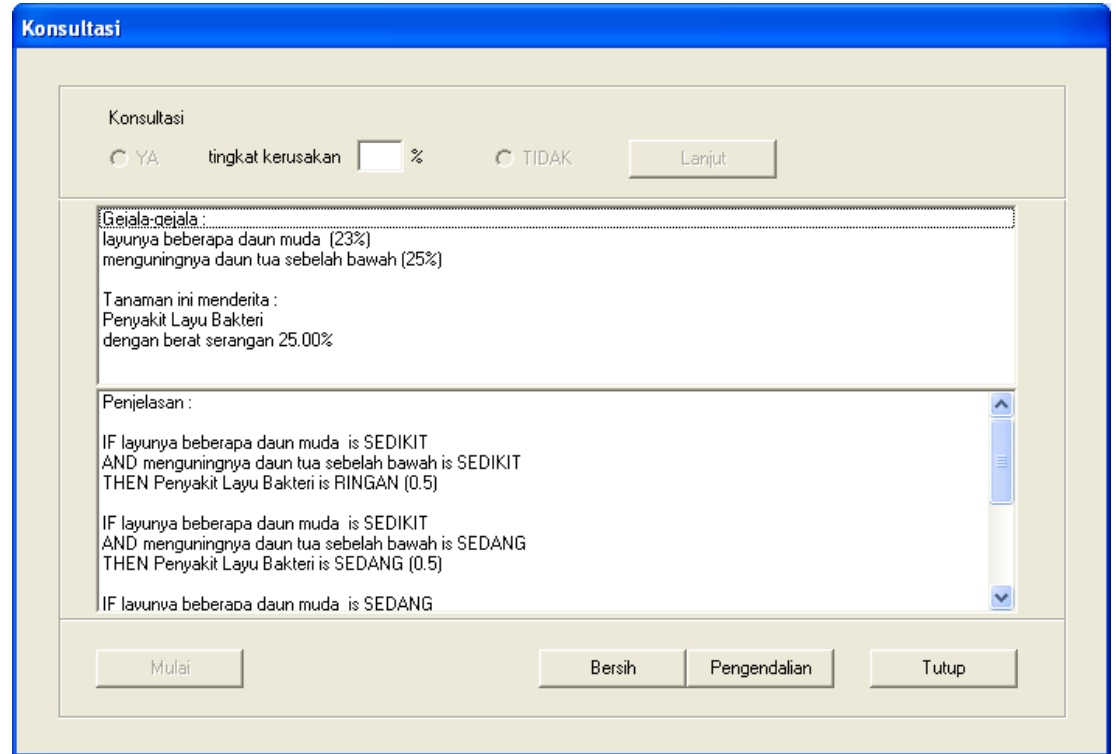

Gambar 3.8 Form menampilkan hasil konsultasi

\section{KESIMPULAN DAN SARAN}

\subsection{Kesimpulan}

Berdasarkan hasil penelitian yang telah dilakukan dapat disimpulkan beberapa hal sebagai berikut :

1. perangkat lunak sistem pakar menggunakan mesin inferensi fuzzy yang telah dibangun dapat digunakan untuk menentukan penyakit pada tanaman cabe merah.

2. Data input tingkat kerusakan pada gejala tanaman dinyatakan sebagai nilai crisp dan data output berat serangan penyakit pada tanaman juga bernilai crisp.

3. Inferensi fuzzy digunakan untuk menentukan berat serangan penyakit. Berat serangan ini menentukan cara pengendalian yang dipakai untuk menanggulangi penyakit tersebut.

4. Data tanaman dan gejala terserang penyakit yang akan digunakan untuk membentuk aturan disimpan dalam file basis data, sehingga data baru dapat ditambahkan ke dalam sistem tanpa mempengaruhi mesin inferensi fuzzy yang telah dibangun.

5. Output dari sistem pakar tersebut berupa jenis penyakit dan berat serangannya, serta dilengkapi dengan cara pengendaliannya. 


\subsection{Saran}

Penelitian lebih lanjut perlu dilakukan terutama dalam hal:

1. Pembuatan fasilitas pengecekan dalam input data/fakta dan aturan sehingga tidak terjadi duplikasi data aturan.

2. Pengujian lebih lanjut untuk jenis tanaman lain.

3. Perbandingan hasil sistem pakar dengan menggunakan metode inferensi, komposisi dan defuzzifikasi yang lain.

4. Pengolahan data input tingkat kerusakan pada gejala tanaman berupa himpunan fuzzy.

\section{UCAPAN TERIMAKASIH}

Dalam kesempatan ini penulis mengucapkan terima kasih kepada Kopertis Wilayah $\mathrm{V}$ yang telah membiayai penelitian ini pada tahun anggaran 2009.

\section{DAFTAR PUSTAKA}

Firebaugh M. W., 1989, Artificial Intelligence. A Knowledge-Based Approach, PWS-Kent Publishing Company, Boston.

Havinga H.N.J, van der Veer P., Brouwer, J. Cser., 1999, Fuzzy Logic, Technical Report. Faculty of Civil Engineering and Geosciences, Delft University of Technology, Netherlands.

Klir, G. J \& Y. Bo., 1995, Fuzzy Set and Fuzzy Logic: Theory and Applications. Prentice-Hall International, Inc, New Jersey.

Negoita, C. V., 1985, Expert Systems and Fuzzy Systems. The Benjamin/cummings Publishing Company, Inc. California.

Semangun, Haryono, 2007, Penyakit-Penyakit Tanaman Hortikultura Di Indonesia (Edisi Kedua), Gadjah Mada University Press, Yogyakarta.

Turban, Efraim, 1995, Decision Support System and Expert System, $4^{\text {th }}$ ed., Prentice-Hall, Inc., New Jersey, pp 472-679

Wang, L. 1997. A Course in Fuzzy Systems and Control. Prentice-Hall International, Inc., New Jersey.

_, 1992, Hama Penyakit Sayuran Dan Palawija, Penerbit PT. Penebar Swadaya, Anggota IKAPI, Jakarta. 